【論 文】

UDC : 624. 042. $7: 699.842$
日本建築学会構造系論文報告策 第 419 号・1991 年 1 月 Journal of Struct. Constr. Engng, AIJ, No.419, Jan., 1991

\title{
実構造物における制振効果の検証
}

水のスロッシングを利用した制振装置の研究（その2）

\section{VERIFICATION OF VIBRATION CONTROL EFFECT IN ACTUAL STRUCTURE Study of vibration control damper using sloshing of water (Part 2)}

\author{
野路利幸*, 吉田英敏**, 立. 見栄司***, 小坂英 之****, 萩生田 弘***** \\ Toshiyuki NOJI, Hidetoshi YOSHIDA, Eiji TATSUMI, Hideyuki KOSAKA \\ and Hiroshi HAGIUDA
}

\begin{abstract}
The vibration control effect in an actual structure of a vibration control damper using the fluid force of water is discussed in this study. The building where the damper was applied is a tall panoramic tower $158 \mathrm{~m}$ in height. The damper was installed to reduce vibration of the building in the transverse direction due to wind.

Forced vibration experiments, free vibration tests, microtremor measurements, and wind vibration observations were carried out for cases with and without the damper in order to verify the vibration damping effect of the damper.

The following conclusions were drawn as a result of these tests and observations :

(i) It was ascertained that this vibration control damper was effective against steady-state and random forces.

(ii) The calculated value according to the analysis technique proposed corresponded well with experimental values.
\end{abstract}

Keywords : damper, vibration control, water, vibration test

1.はじめに

本研究は，水のスロッシングを利用した制振装置の高 層構造物における有効性を論じるものである。近年, 液 体, 特に水の摇動を利用した制振機構は, 微振動レベル から効果を発揮すること,構造が簡単で故障がないこと， 周期の調節が容易なこと，維持管理が容易なことなどの 利点から，風や地震による構造物の横摇れを抑制するた めの有効な制振方式として注目されはじめ, 活発に研究 が進めら机てきている(例えば，文献 1) 〜6))。筆者ら は, 本研究 (その 1) で, 角型水槽を用いてその中に形 状比 (水槽長/永深) の比較的小さい「深い水」を配し, 装置の減衰機構として減衰ネットと呼んでいる金網を設 置した制振装置について，装置の流体力特性を把握する
とともに，高層建物における制振効果を解析的に検討し $た^{71}$ 。

本研究（その 2）では，実構造物への適用性という観 点から, 本装置を実建物に適用し, 装置のなし・ありの 両ケースについ;行った強制振動実験, 自由振動試験, 常時微動測定, および風摇れ観測結果から, 本制振機構 の定常・非定常外乱に対する制振効果を検討し，適用の 妥当性について論じる。

\section{2. 建物概要}

図一 1 に本装置を適用した建物の平面および断面図を 示す。本建物は，1988 年 3 月に香川県宇多津町に完成 した軒高 $136 \mathrm{~m}$, 最高部高さ $158 \mathrm{~m}$ の高層展望タワーで,

\footnotetext{
本論文は，日本建築学会大会において発唛した概姴81ー10)に再検討を加え，まとめたものである。

* 三井建設 (株) 技術開発本部技術研究所 所長代 Technical Research Laboratory, Research and Development Division, 理·工修

** 三井建設 (株) 設計本部構造開発設計部 室長

*** 三井建設 (株) 技術開発本部技術研究所 主任研 究員・工修 Mitsui Construction Co., Ltd. M. Eng. Mitsui Construction Co., Ltd. M. Eng.

Structural Design Department, Mitsui Construction Co., Ltd.

**** 三井建設 (株) 技術開発本部技術研究所 研究 Technical Research Laboratory, Research and Development Division, 員・工蓚 Mitsui Construction Co., Ltd. M. Eng.

***** 三井造船 (株) 鉄構土木事業部鉄構技術部 課長 Steel Structure \& Civil Engineering.Headquarters, Mitsui Engineering 補佐 \& Shipbuilding Co., Ltd.
} 


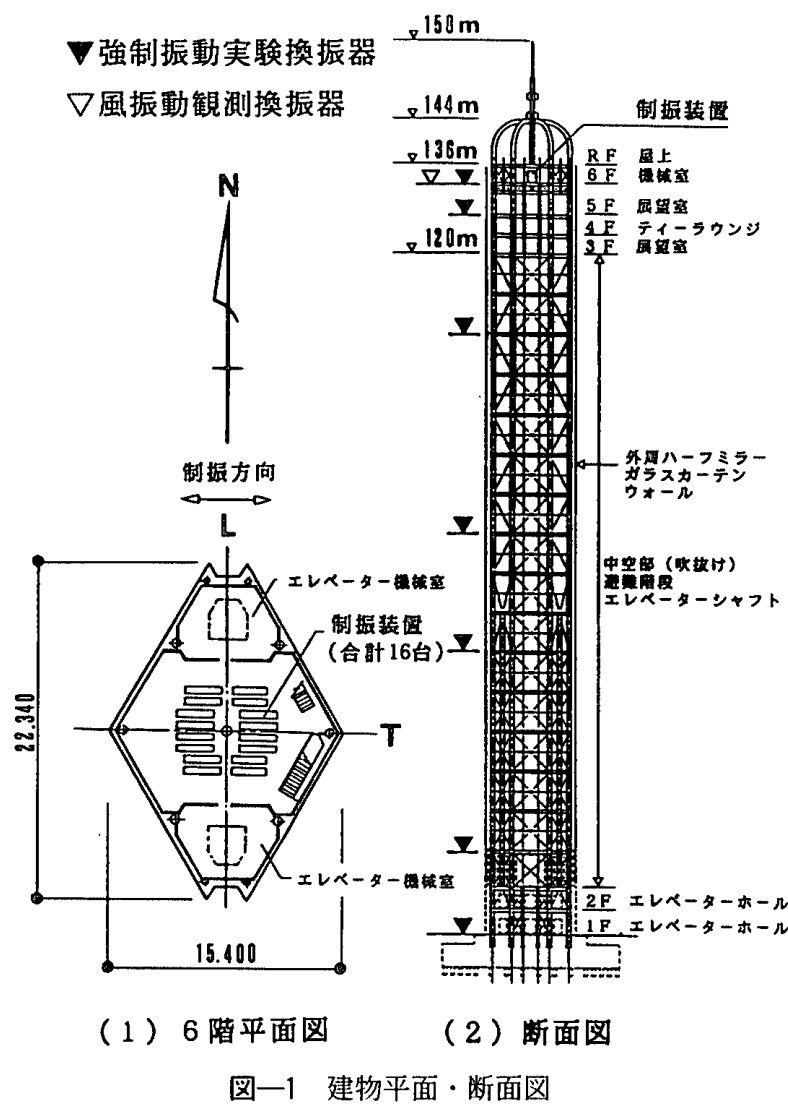

平面形状は鋭角部を切り落とした扁平な菱形形状をして いる。頂部 3 層が展望室で, 低層部から展望室までの中 間部の約 $100 \mathrm{~m}$ は吹抜けとなっている。構造は, 基部 2 層が鉄骨鉄筋コンクリート造, 上尿部が鉄骨造である。 建物外周は, 全面がガラスカーテンウォールで覆われて いる。

本建物は, 細高い立面形状をしていること, 中空で軽 いこと, 鉄骨造で減衰性が低いことなど展望タワーとい う建物の性格上, 特に短手方向が風に対して摇れやすい 構造である。このため, 季節風などの比較的頻度の高い 強風時の居住性および使用性という観点から, 建物の上 層部で数 gal から数十 gal 程度の比較的小振動レベルを 対象に制振装置の設置を計画した。

\section{3. 制振装置とその流体力}

\section{1 制振装置の設計}

制振装置は，図一2に示す設計フローに従って設計を 行った。設計にあたって, 水の質量比は $1 \sim 1.5 \%$, 形 状比は 4〜6を目安とし, 水槽形状は設置階における配 置とそこへの搬入を考慮して決定した。1ユニットは, 図一 3 に示すように長さが $2.5 \mathrm{~m}$, 幅が $0.45 \mathrm{~m}$, 高さが $1.0 \mathrm{~m}$ のステンレス製水槽で, 建物最上部の機械室に短 手方向を制振対象方向として 16 基設置した。写真一1 に装置の設置状況を示す。水深は, 振動実験結果による 建物の 1 次周期に同調させて $0.53 \mathrm{~m}$ （形状比 4.7）と している。水の重さは, 1 基が約 $0.60 \mathrm{t}$, 合計で $9.5 \mathrm{t}$

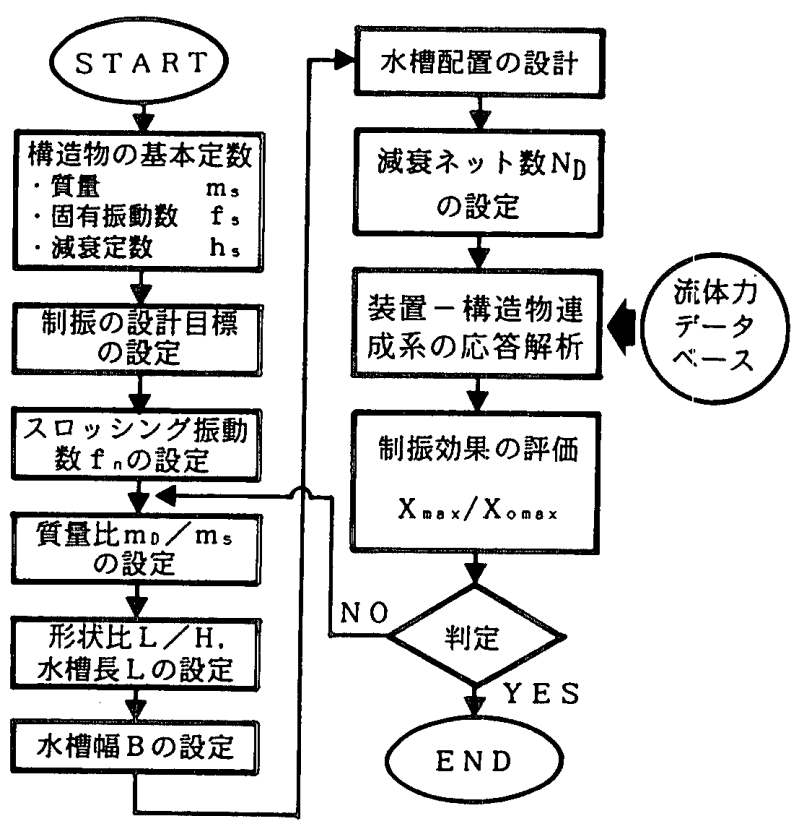

図一2 制振装置の設計フロー

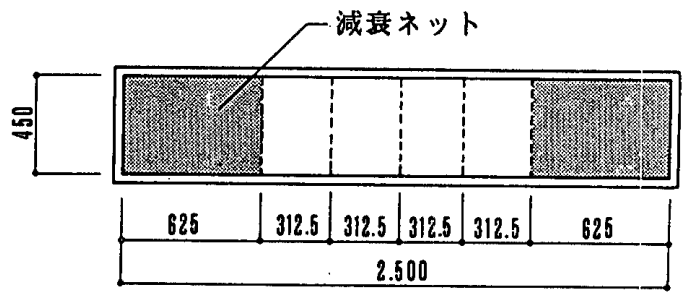

(1) 平面困

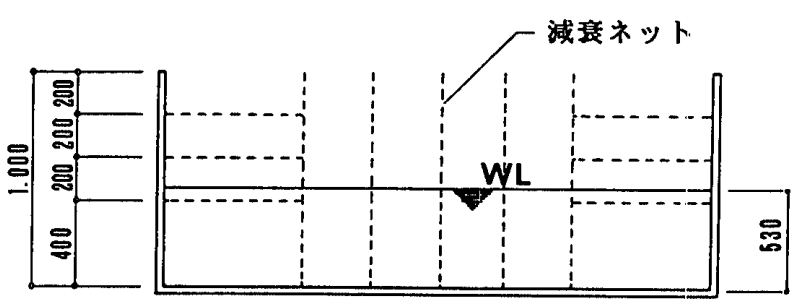

(2) 断面図

図-3 装置図

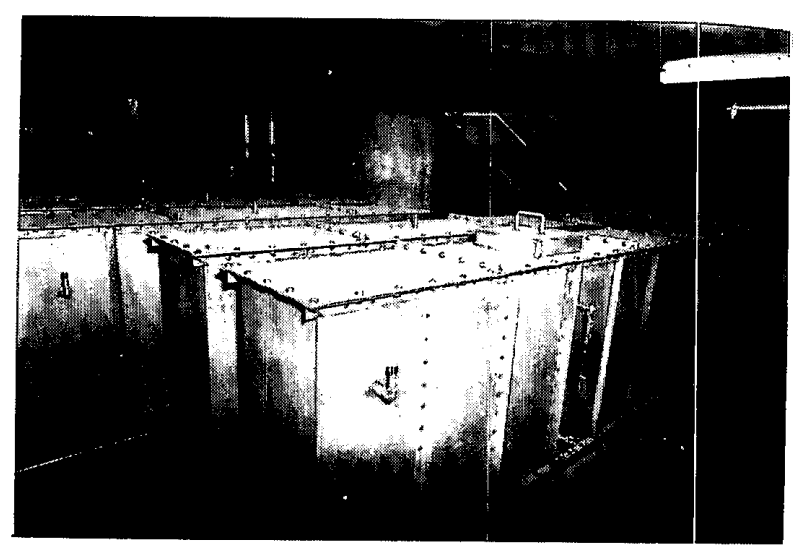

写真一1＼cjkstart装置の設置状況

であり，建物の 1 次の一般化重量の約 $1.3 \%$ である。 減衰ネットは, 素線径が $1.1 \mathrm{~mm}$, 開口率が $51.3 \% の$ ステンレス製金網（標準ふるいJIS Z 8801）で，垂直 
方向に 5 枚, 両端部で水平方向に 3 枚づつ配置されてい る。

\section{2 制振装置の流体力}

図一4に制振装置単体の加振実験から得られた無次元 流体力の振幅 $P / P_{o}\left(P\right.$ : 流体力, $P_{o}$ : 水重量を固定亡 みなした慣性力）と位相 $\phi$ をを示す。実験方法は，水平 一方向のスライドテーブルとアクチュエータを用いた加 振振幅一定の強制振動実験である。加振振幅は 1 200 $\mathrm{mm}$, 加振振動数は無次元振動数 $f / f_{n}(f:$ 加振振動数, $f_{n}$ : ポテンシャル理論によるスロッシング固有振動数）

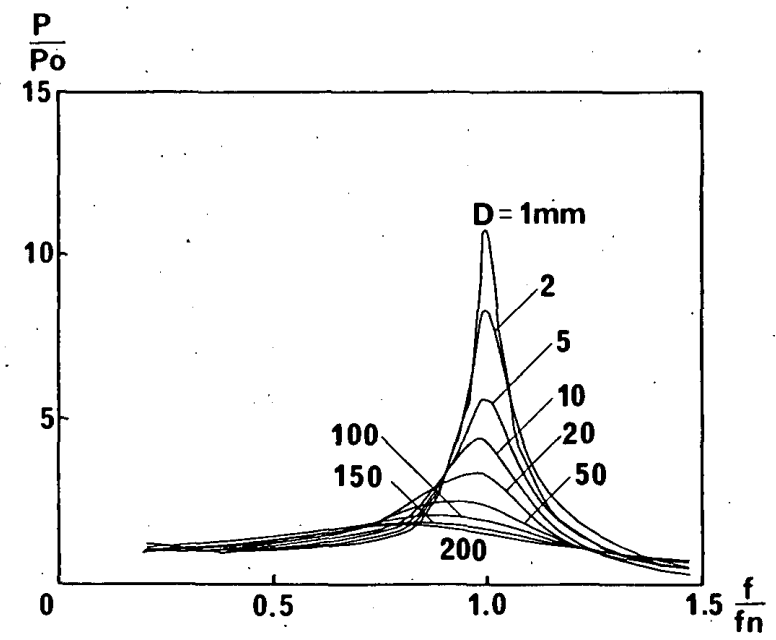

(1) 振幅

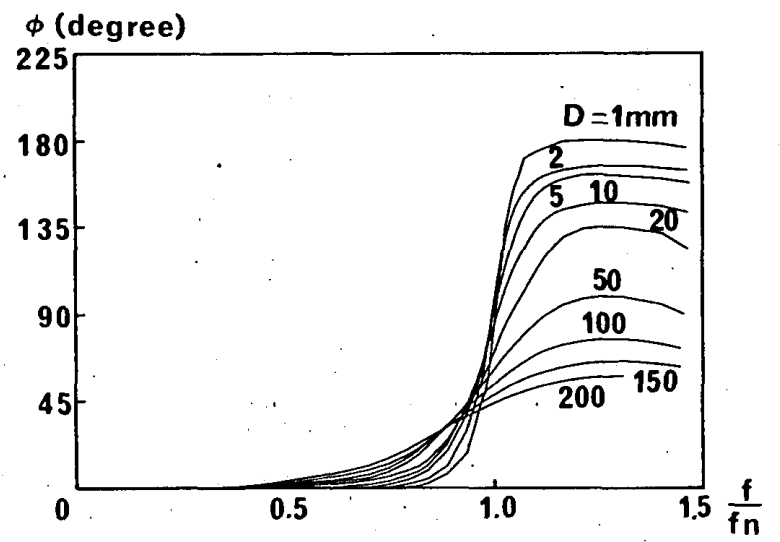

(2) 位相

図一4 装置の流体力

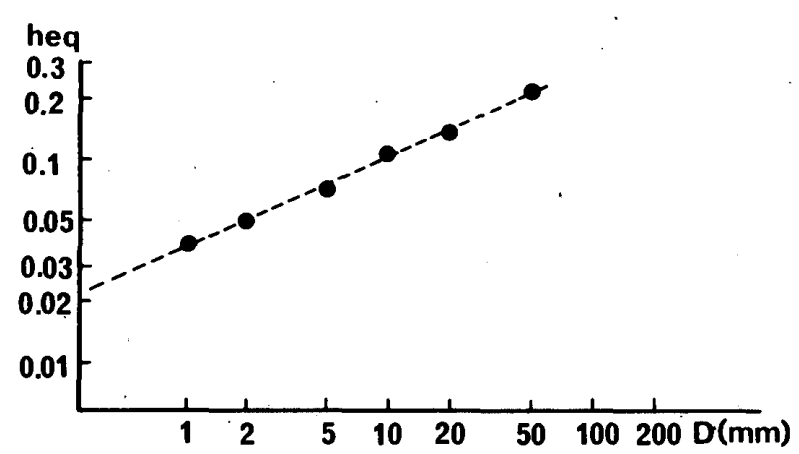

図一5 加振振幅上装置の等価诚衰定数の関係
で 0.2 - 1.4 である。無次元振動数が 1.0 付近で流体力 振幅はピークを示し，位相はほぼ $\pi / 2$ となる。ただし， 図から明らかなように，流体力の振幅，位相とも強い振 幅依存性を示し, 加振振幅が大きくなるほどピークはな だらかに，また位相の変化は緩やかになる。

図一5 は加振掁幅 $D$ と装置の等価減衰定数 $h_{e q}$ の関係 を示したものである。等価減衰定数は; 加振振幅力゙増加 するのに伴って両対数グラフ上でほぼ直線的に増加する 傾向を示す。本建物が対象とする制振範囲は，主として 加速度で数 $\mathrm{gal} \sim$ 数十 gal, 変位で数 $\mathrm{mm}$ 数十 $\mathrm{mm}$ で あり, 従って等価減衰定数としては 5 15\% 程度が期 待されることになる。

他方, 装置の流体力にフルードの相似則が成り立つこ とを確認すること, さらにそれに基づいて大地震時や暴 風時などの大振幅状態での装置の性状を把握することの 2 点を目的として; 図一 6 に示す実機の $1 / 2.5$ 縮尺の模 型水槽を用いた加振実験を行った。水槽長は $1.0 \mathrm{~m}$, 水 深は $24 \mathrm{~cm}$ で, 形状比は 4.2 である。また, 流体力の 減衰特性は（その1) で述べたように，減衰ネットにか かる水の玨力, すなわち圧力損失量から決まり,この力 はネットの開口率および枚数に依存するため,ここでは 簡略化してネットは実機と同一のものを用い, 垂直方向 に 5 枚配置した。加振振幅は, 振幅拡大装置を用いて 1 一 $500 \mathrm{~mm}$ とした。

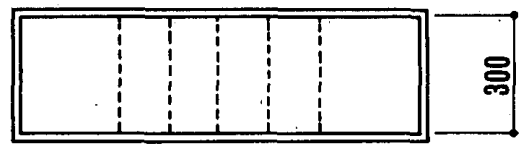

(1) 平面図

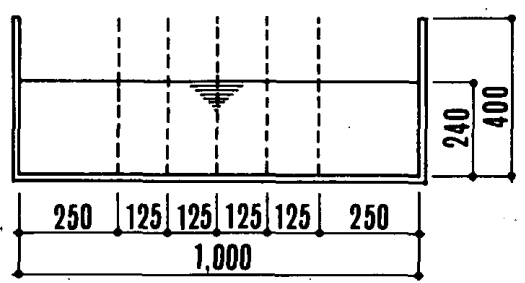

(2) 断面図

図一6 縮小水槽試験体

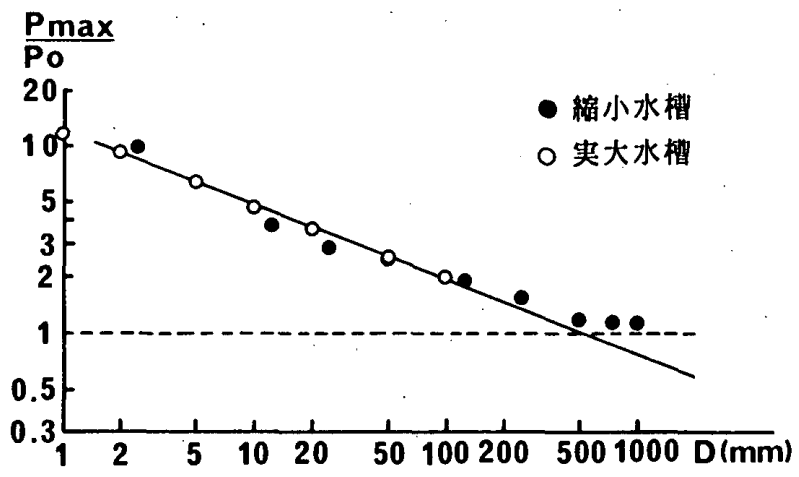

図一7 加振振幅と流体力の最大応答倍率の関係 
図-7 に，実大換算の加振振幅と無次元流体力の最大 応答倍率の関係を同一形状比の実大水槽の実験結果と比 較して示す。この結果, フルードの相似則に基づいた縮 小水槽の実大換算值之実大水槽の実験結果はほぼ一致し ており，流体力に関する相似則が成り立っていることが 分かる。また, 応答倍率は, 加振振幅が $100 \mathrm{~mm}$ 程度ま では振幅が増加するのに伴って両対数グラフ上で直線的 に減少していくが, 砕波が発生する $100 \mathrm{~mm}$ 以上の大振 幅域では 1.0 に漸近する傾向を示す。このことは，大振 幅域では，流体力は次第に水重量を固定とみなした慣性 力に収束し, 大地震時や暴風時に構造物に対して不都合 な影響を与えないことを示している。

\section{4. 実構造物における制振効果の検証}

\section{1 実験および観測概要}

建物の竣工直前の 1988 年 2 月に, 装置の設置による 制振効果を確認するために，制振装置のない場合（以下， 「装置なし」）とある場合（以下，「装置あり」），すなわ ち水のなし・ありの 2 ケースについて強制振動実験, 自 由振動試験, および常時微動測定を行った。

強制振動実験は, 定常加振による建物の周波数応答特 性を把握することを目的として，建物の 5 階に設置した 起振機 (BCS-A-200) で建物を強制加振し, 建物各点 の変位，および水槽のスロッシング波高を測定した。加 振モーメントは 20 - $200 \mathrm{~kg} \cdot \mathrm{m}$, 加振周波数範囲は 0.3 - $4.0 \mathrm{~Hz}$ である。自由振動試験は, 建物の減衰定数の 把握を目的として, 起振機の急停止による建物の自由振 動波形を測定した。また，常時微動測定は，不規則外乱

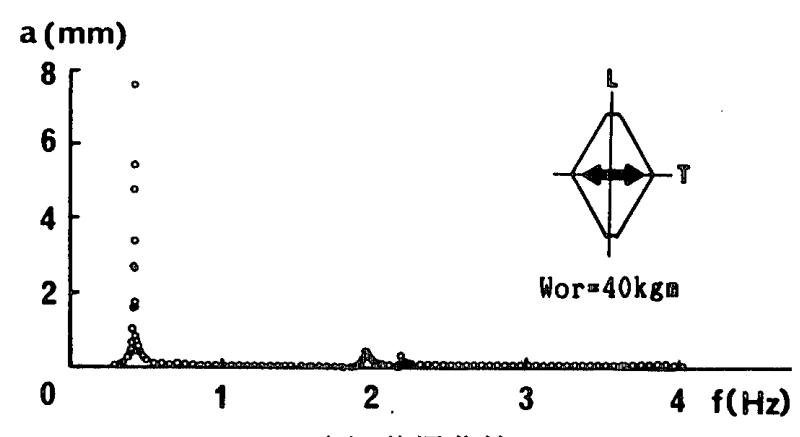

(1) 共振曲線

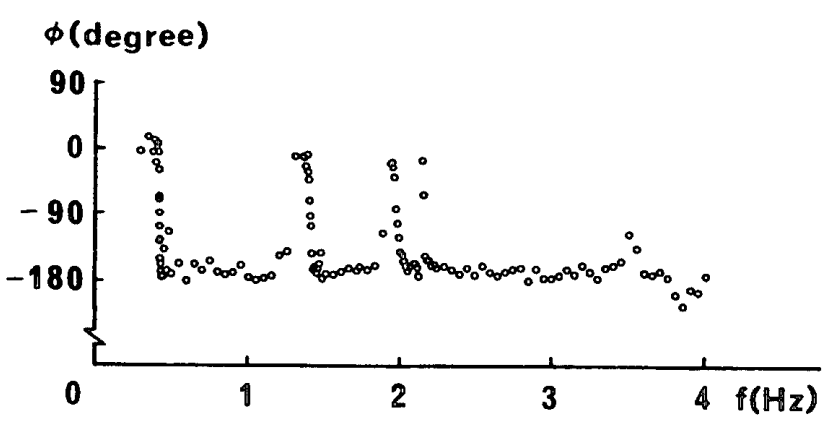

(2) 位相曲線

图一8「装置なし」の建物の周波数忘答特性
に対する有効性，および微振動レベルでの制振効果の把 握を目的として，風および工事振動の影響が比較的少な い時に，建物 2 方向の速度波形を測定した。

一方，建物竣工後，および竣工 1 年目の定期検查を機 会に，風による建物の振動応答特性を調查するために風 摇れ観測を行った。風向風速計は地上 $148 \mathrm{~m}$ の鉄塔に 設置し， 6 階に設置した 3 台の速度型換振器により建物 2 方向の速度波形を観測した。

\section{2 強制振動実験による制振効果の検証}

\section{2 .1 「装置なし」の建物の周波数応答特性}

図一8に「装置なし」の短手方向（ $T$ 方向）の共振曲 線および位相曲線を示す。共振曲線には建物の 1 次の鋭 いピークと 2 次の低いピークが見られる。

表一1は，共振曲線のピークおよび位相曲線より求め た建物の固有振動数と，共振曲線より $1 / \sqrt{2}$ 法で求めた 減衰定数である。固有振動数は，全般的に実験値が設計 值よりやや高いが，よい対応を示している。特に，長手 方向（ $L$ 方向）に比べて外周のカーテンウォールの剛 性の影響がより小さいと思われる $T$ 方向ではかなりよ く一致している。一方, 堿衰定数は, 建物頂部の加速度 が 3〜 $5 \mathrm{gal}$ 程度の微振動時のものであり, 1 次では $T$ 方向で $0.35 \%, L$ 方向で $0.60 \%$ と比較的小さい值之 なっている。

\section{2 .2 「装置あり」の建物の周波数応答特性}

図一9に「装置あり」の $T$ 方向の共振曲線を示す。 また, 図一10には 1 次共振点付近の拡大図を, 装置の なし・ありで比較して示す。なお，図一10中の実線は 計算値で，これに関しては次節で詳しく述べる。これら の結果から，「装置あり」では $0.422 \mathrm{~Hz}$ の鋭いピークに 代わって $0.40 \mathrm{~Hz}$ と $0.44 \mathrm{~Hz}$ の 2 か所に低いピークが現

表一1 建物の固有振動数と減衰定数（「装置なし」）

\begin{tabular}{|c|c|c|c|c|c|c|c|c|}
\hline \multirow{2}{*}{ 方向 } & \multicolumn{3}{|c|}{ 振動数実験值 $(\mathrm{Hz})$} & \multicolumn{3}{|c|}{ 振動数設計值 (Hz) } & \multicolumn{2}{|c|}{ 减期定数 (96) } \\
\hline & 1 次 & 2 次 & 3 次 & 1 次 & 2 次 & 3 次 & 1 次 & 2 次 \\
\hline $\mathrm{T}$ 方向 & 0.422 & 1.94 & 3.91 & 0.400 & 1.91 & 3.76 & 0.35 & 1.1. \\
\hline L方向 & 0.422 & 1.98 & 3.86 & 0.371 & 1.88 & 3.56 & 0.150 & 1.3 \\
\hline かじ & 1.41 & 3.55 & - & 1.16 & 2.88 & - & 1.10 & 5.2 \\
\hline
\end{tabular}

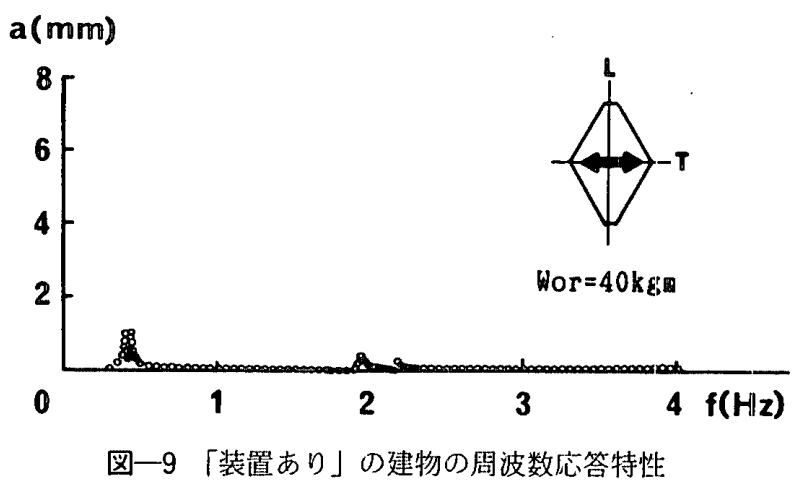


れ，1 次振動に対する顕著な制振効果が認められる。最 大振幅で比較すると, 約 $8 \mathrm{~mm}$ から $1 \mathrm{~mm}$ へとほぼ $1 / 8$ に減少している。また，図一 8 と図一 9 の比較から明ら かなように, 1 次共振点以外では装置のなし・ありによ る共振曲線の変化は見られない。

図一11 は，加振力を変化させた場合の共振曲線で, 応答変位を起振モーメントで除して基準化したものであ る。装置の減衰性能が振幅依存性を有しているため, こ れらの共振曲線は一致せず，加振力が大きくなるに従っ て山と谷が緩やかになり，装置の減衰性が增加すること を示している。

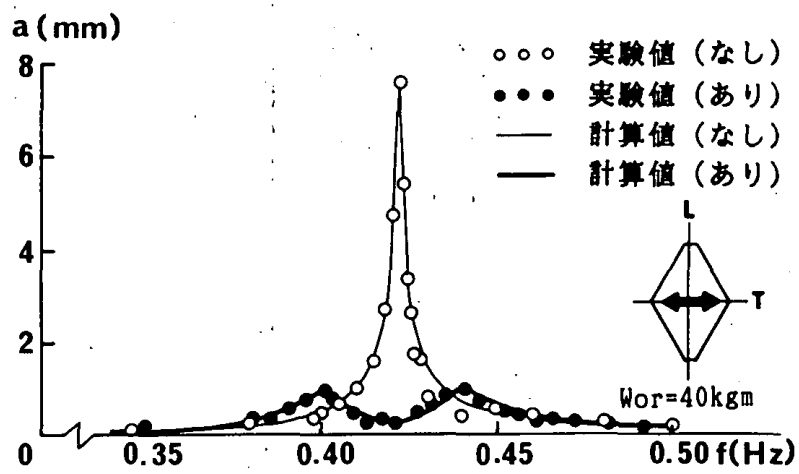

図一10「装置なし・あり」の 1 次付近の共振曲線の比較

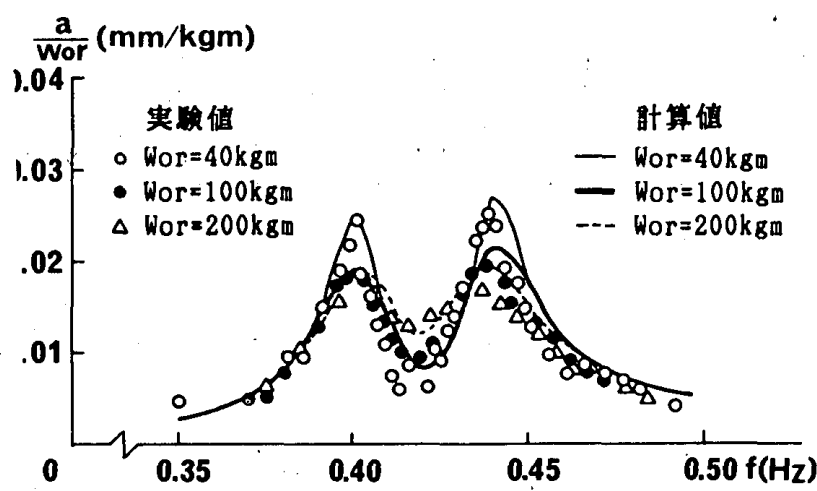

図一11. 加振力を変化させた場合の共振曲線

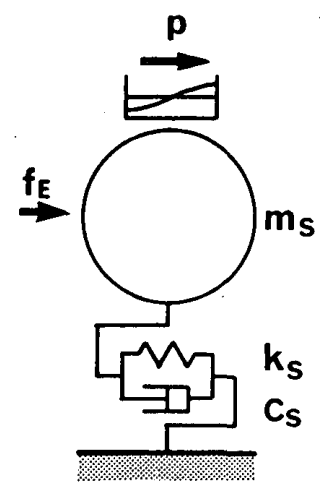

(1) 流体力モデル

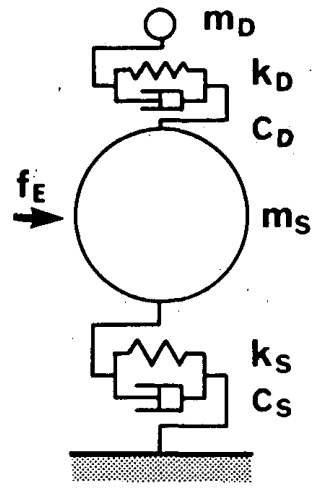

(2) T MDモデル
図一12 制振機構の振動モデル
4.2.3 実験結果のシミュレーション解析.

（1）流体力モデルによる解析

装置の減衰特性が振幅依存性を有する本制振機構の周 波数応答解析手法として, 筆者らは, 装置の加振実験か ら得られる流体力を用いる解析手法を提案した?!。こ では，この流体力モデルによる解析手法を用いて奏験結 果のシミュレーション解析を行い, 解析手法の妥当性を 検討する。

いま，構造物を 1 自由度系とすると，図一12(1)に 示す装置一構造物連成系の振動モデル（流体力モデル） が起振機による調和加振力を受けた時の周波数応答解 は, 次式で表される。

$$
\begin{aligned}
& 1-\omega^{2} \cdot m_{s}+i\left(\omega \cdot c_{s}-\left(P\left(U_{s}\right) / U_{s}\right) \sin \phi\right)+k_{s} \\
& \quad+\left(P\left(U_{s}\right) / U_{s}\right) \cos \phi \cdot \cdot U_{s} \cdot e^{-i \varphi}=w_{o} r / g \cdot \omega^{2}
\end{aligned}
$$

ここで, $m_{s}, c_{s}, k_{s}$ : 構造物の質量, 減衰係数, ばね 定数, $w_{o} r:$ 加振モーメント, $g$ : 重力加速度, $\omega$ : 加 振円振動数, $U_{s}$ : 構造物の変位振幅, $P\left(U_{s}\right)$ : 流体力 の振幅, $\psi$ : 加振力に対する構造物変位の位相, $\phi$ : 構 造物変位に対する流体力の位相

上式に対し，装置の流体力として 3 章の無次元流体力 の振幅 $\left(P\left(U_{s}\right) / U_{s}\right)$ 之位相（ $\left.\phi\right)$ のデー夕を用いて，

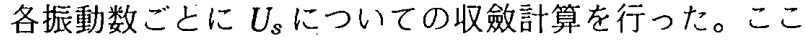
で, 建物は等価な 1 質点系に置換し, 振動諸元は, 一般 化重量を $708 \mathrm{t}$ ，ば姳定数を $5.08 \mathrm{t} / \mathrm{cm}$ ，減衰定数を $0.35 \%$ とした。また, 任意振幅における流体力は, 各 加振振幅の流体力の值を直線補間して用いた。

図一 10,11 に，共振曲線の計算值を実験值と比較し て示す。計算值は夷験値とよい対応を示している。図一 11 は，起振モーメントで基準化した共振曲線であり， 計算値に加振力の相違による振幅依存性が反映されてい ることが分かる。これらの結果から，流体力モデルによ る解析手法は本制振機構の解析に妥当であるといえる。

(2) 同調質量ダンパー (TMD) モデルによる解析

装置の流体力が非線形性を有しているため, 本制振機 構の忘答解析法としては前項で述べた流体力モデルによ る解析法が適切であると考えられる。しかしながら，本 解析法は不規則外乱に対しては適用が困難であること, また，実用的な面からは簡易モデルで制振効果を推定で きることが望ましいことの 2 点から，解析に通常の線形 モデルが適用可能であれば都合がよい。そこで，本制振 機構の理論解析に, 重鍾, ばね, および減衰機構から構 成されるTMD (Tuned Mass Damper) モデルの適用 性を検討するため，実験結果と図一12(2) に示す TMD モデルによる解析結果との比較を行った。建物定 数は前項と同一とし，TMDはHousner ${ }^{11)}$ による自由水 重量を装置重量とする振動モデルに置換した。装置の重 量は $7.03 \mathrm{t}$,ばね定数は $0.050 \mathrm{t} / \mathrm{cm}$ である。減衰定数 
については振幅依存性を有しているため, 図一5の加振 振幅と等価減衰定数の関係をもとに, 実験結果の最大忍 答振幅の $60 \%$ を加振振幅とした時の値とした。

TMD モデルによる解析結果と実験結果との比較を図 ー13に示す。TMD モデルによる共振曲線は奏験結果 とよく一致しており，波高および流体力の応答倍率から 等価減衰定数が求められる砕波のない領域では，制振効 果はTMD 理論で推定可能なことを示している。

4.3 自由振動試験による制振効果

図一14 は, $T$ 方向の自由振動波形を 装置のなし・ありで比較したものであ る。「装置なし」では振動が長く継続し ているのに対して，「装置あり」では振 動がすみやかに減衰し，装置設置の明ら かな効果が表れている。娍衰定数で比較 すると,「装置なし」の0.35\%に対して， 「装置あり」では3〜4\%を示し，大幅 な減衰の堌加が認められる。なお，「装 置あり」の波形の後半部においてうなり 現象が生じているのは, 微小振幅領域で は装置の減衰性能が小さくなるためであ る。

4.4 常時微動および風摇れ観測による 制振効果の検証

4.4 .1 常時微動特性

図一15 は，装置のなし・ありの 4 分

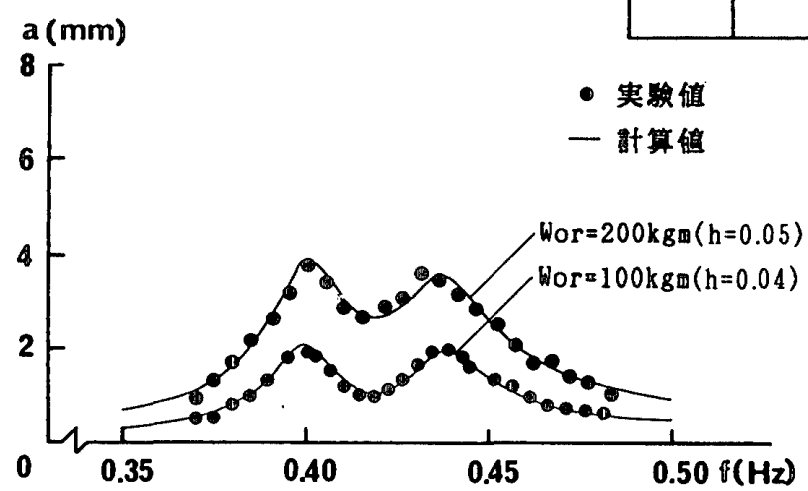

図一13 TMD モデルによる解析結果よ実験結果の比較

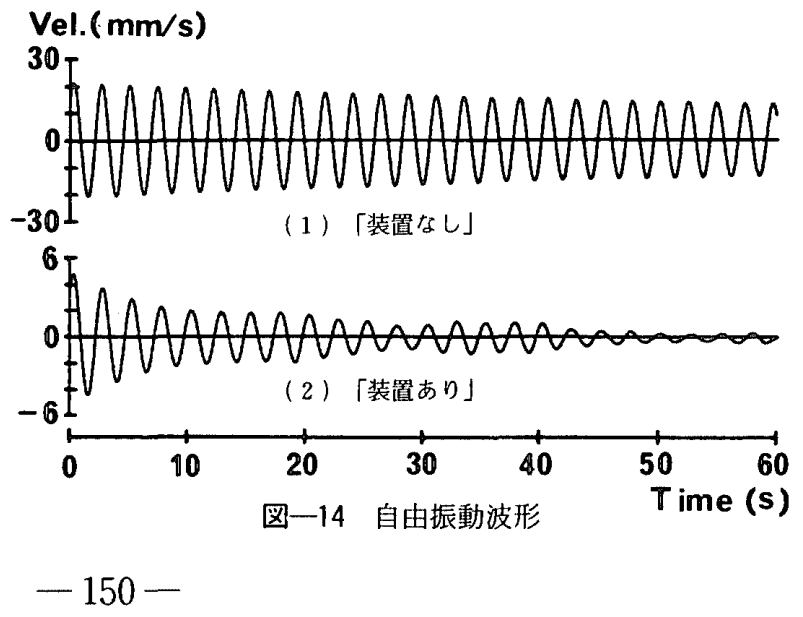

間の常時微動波形を比較したものである。「装置なし」 では両方向の波形の性状はほぼ同じであるのに対しで， 「装置あり」では $T$ 方向の波形の特性は大きく変化し， 建物の減衰性が増加したことを示している。装置のな し・ありで外力条件は必ずしも同一ではないが，本装置 が不規則外乱に対しても有効であること，および常時微 動のレベルから作動していることが分かる。

\section{4 .2 風摇れ特性}

表一2に風摇れ観測結果の一覧を示す。各観測記録の 表一2 風摇れ観測一覧

\begin{tabular}{|c|c|c|c|c|c|c|c|}
\hline \multirow{2}{*}{$\begin{array}{l}\text { 薜罪の } \\
\text { 状 況 }\end{array}$} & \multirow{2}{*}{ 湘定日 } & \multirow{2}{*}{$\begin{array}{c}\text { 平均風向 } \\
\text { (方位) }\end{array}$} & \multirow{2}{*}{$\begin{array}{l}\text { 平均風速 } \\
(\mathrm{m} / \mathrm{s})\end{array}$} & \multicolumn{2}{|c|}{ 最大值 $(\mathrm{cm} / \mathrm{s})$} & \multicolumn{2}{|c|}{ 標盤倡美: (cm/s） } \\
\hline & & & & L方向 & $\mathrm{T}$ 方向 & L方向 & $\mathrm{T}$ 万问 \\
\hline $\begin{array}{ll}\text { 装 } & \text { 置 } \\
\text { な } & \text { L }\end{array}$ & $\begin{array}{r}39 / 10 \\
3 / 11 \\
3 / 11 \\
3 / 11 \\
3 / 11 \\
3 / 14 \\
3 / 14 \\
3 / 14 \\
3 / 14 \\
3 / 14 \\
3 / 14 \\
3 / 15\end{array}$ & $\begin{array}{l}\text { 南西 } \\
\text { 南西 } \\
\text { 南西 } \\
\text { 南西 } \\
\text { 南西 } \\
\text { 南西 } \\
\text { 南西 } \\
\text { 南西 } \\
\text { 南西 } \\
\text { 南西 } \\
\text { 南西 } \\
\text { 西 }\end{array}$ & $\begin{array}{r}8.1 \\
7.8 \\
10.1 \\
11.1 \\
10.2 \\
10.3 \\
10.2 \\
11.9 \\
12.6 \\
13.0 \\
12.0 \\
10.4\end{array}$ & $\begin{array}{l}0.0438 \\
0.0901 \\
0.1427 \\
0.1369 \\
0.0873 \\
0.1079 \\
0.1080 \\
0.2015 \\
0.2811 \\
0.1958 \\
0.2156 \\
0.0820\end{array}$ & $\begin{array}{l}0.0791 \\
0.1892 \\
0.2599 \\
0.2602 \\
0.1432 \\
0.1738 \\
0.1888 \\
0.3925 \\
0.4008 \\
0.5339 \\
0.3982 \\
0.1002\end{array}$ & $\begin{array}{l}0.0156 \\
0.0336 \\
0.0515 \\
0.0562 \\
0.0378 \\
0.0366 \\
0.0327 \\
0.0605 \\
0.0811 \\
0.0616 \\
0.0738 \\
0.0308\end{array}$ & $\begin{array}{l}0.0289 \\
0.0747 \\
0.0912 \\
0.1105 \\
0.0525 \\
0.0597 \\
0.0667 \\
0.1031 \\
0.1300 \\
0.1213 \\
0.1351 \\
0.0376\end{array}$ \\
\hline $\begin{array}{cc}\text { 装 } & \text { 置 } \\
\text { あ } & \eta\end{array}$ & $\begin{array}{r}88 / 11 / 25 \\
11 / 25 \\
12 / 16 \\
12 / 16 \\
89 / 3 / 9 \\
3 / 9 \\
3 / 9 \\
3 / 16 \\
3 / 16 \\
3 / 16\end{array}$ & $\begin{array}{l}\text { 西 } \\
\text { 西 } \\
\text { 西 } \\
\text { 西 } \\
\text { 南西 } \\
\text { 南西 } \\
\text { 南西 } \\
\text { 南西 } \\
\text { 南西 } \\
\text { 南西 }\end{array}$ & $\begin{array}{r}15.2 \\
11.9 \\
16.7 \\
19.0 \\
10.9 \\
10.7 \\
10.4 \\
8.8 \\
8.0 \\
8.7\end{array}$ & $\begin{array}{l}0.2599 \\
0.1755 \\
0.4893 \\
0.8116 \\
0.1296 \\
0.1309 \\
0.1062 \\
0.0671 \\
0.0760 \\
0.1005\end{array}$ & $\begin{array}{l}0.2379 \\
0.2323 \\
0.5435 \\
0.8898 \\
0.1279 \\
0.1146 \\
0.0998 \\
0.0705 \\
0.0444 \\
0.0557\end{array}$ & $\begin{array}{l}0.1086 \\
0.0674 \\
0.1264 \\
0.2543 \\
0.0359 \\
0.0578 \\
0.0376 \\
0.0233 \\
0.0248 \\
0.0322\end{array}$ & $\begin{array}{l}0.0795 \\
0.0780 \\
0.1191 \\
0.2168 \\
0.0303 \\
0.0333 \\
0.0283 \\
0.0215 \\
0.0132 \\
0.0167\end{array}$ \\
\hline
\end{tabular}
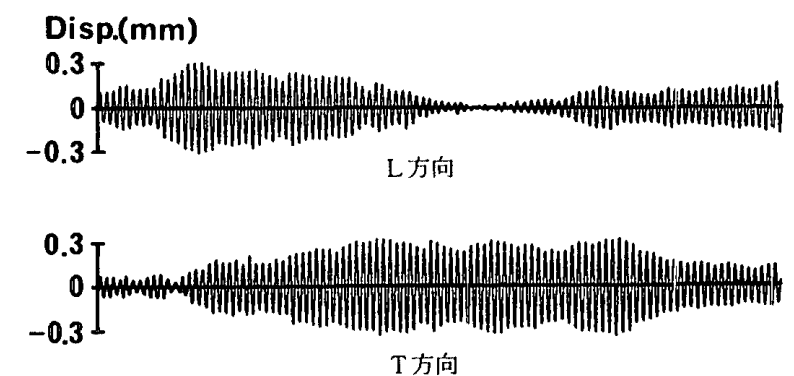

(1)「装置なし」
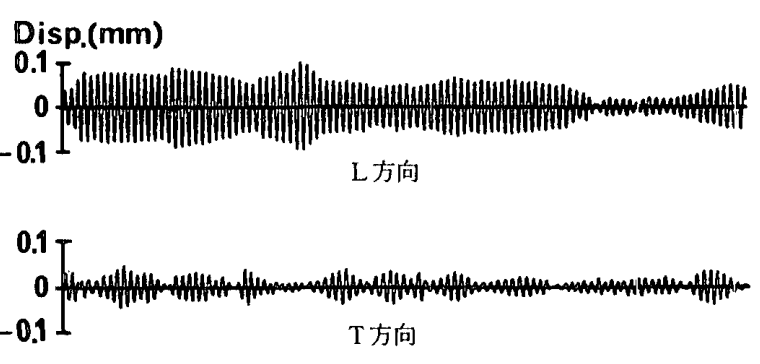

(2)「装置あり」

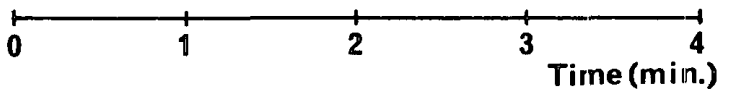

図一15 常時微動波形 


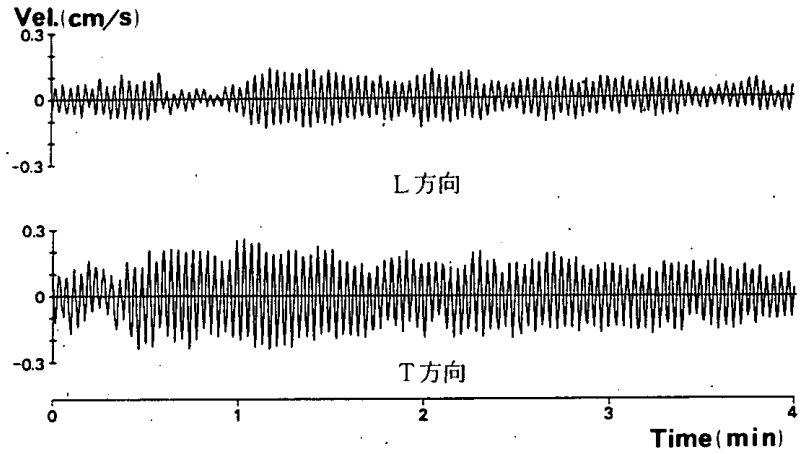

（1）「媴置なし」

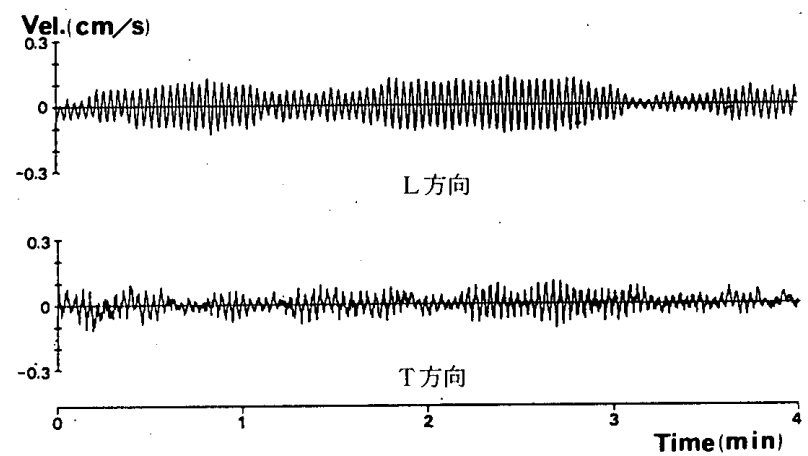

(2)「装置あり」

図一16 風摇れ観測速度波形
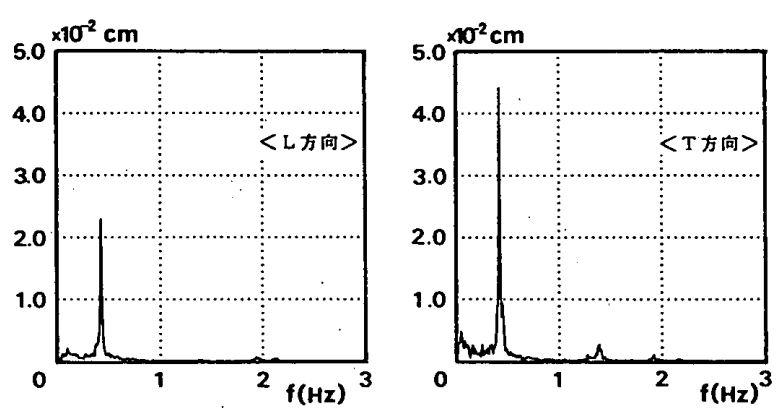

(1) 「装置なし」
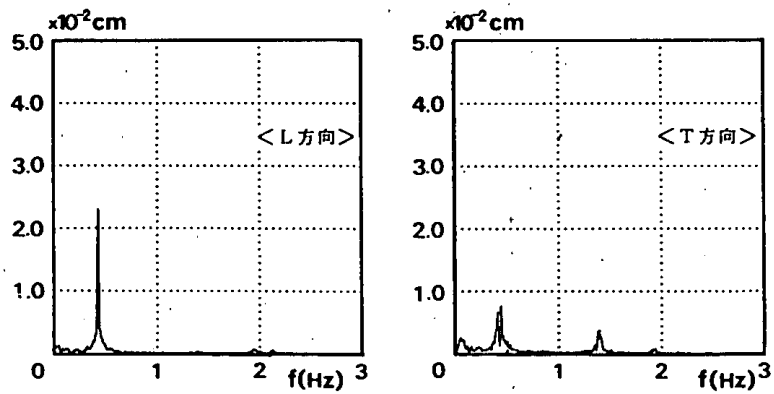

（2）「装置あり」

図一17 速度波形のフーリエスペクトル

長さは, 応答評価時間を考慮して 4 分間とした。観測記 録は，「装置なし」では定期検査時に 12 件，「装置あり」 では定期検查以前に 4 件, 定期検查時に 6 件の計 10 件 が得られた。定期検查以前の記録は冬の季節風で, 建物 頂部における 10 分間の平均風速が $12 \sim 19 \mathrm{~m} / \mathrm{s}$, 平均風 向は西風で，建物の $T$ 方向である。定期検査時は，平 均風速が 8 13 m/s, 平均風向はほとんよ゙が南西の風で,

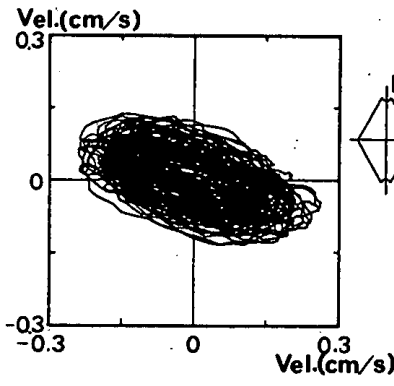

(1)「装置なし」

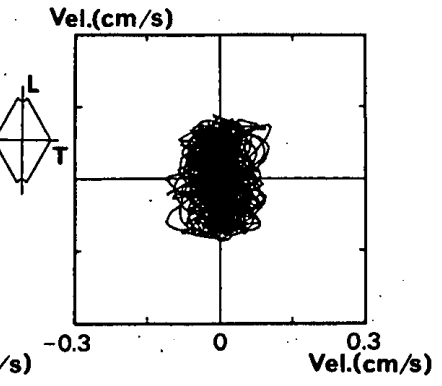

（2）「装置あり」
図一18·速度波形のオービット

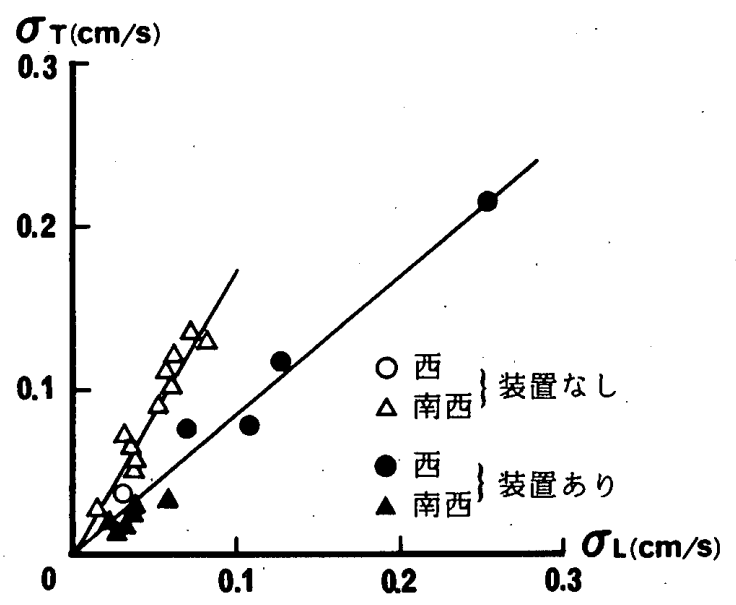

図一19 速度の標準偏差の相関性

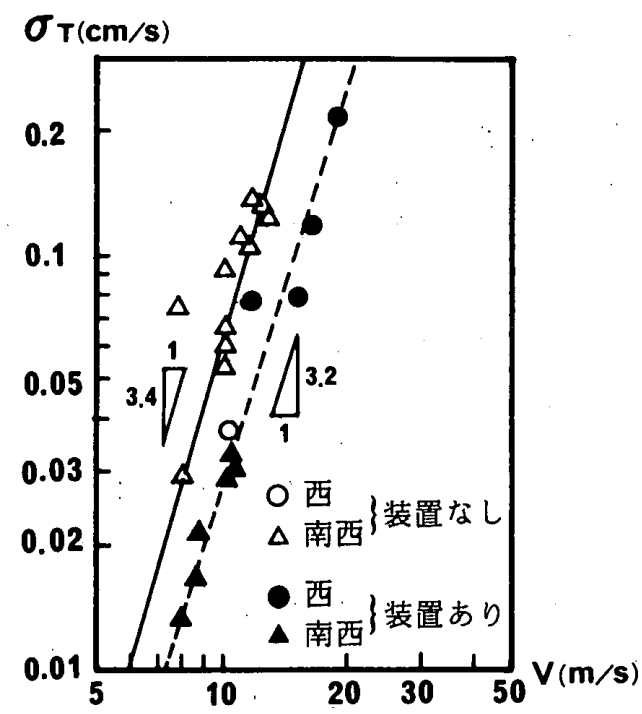

図一20 平均風速と速度の標準偏差の関係

$T$ 方向に対して 45 度方向であった。

図一16に観測波形の一例として，風向，風速，およ び非制振方向である $L$ 方向の最大振幅，標準偏差の条 件がほぼ同一な記録の速度波形を，装置のなし・ありで 比較して示す。制振対象方向である $T$ 方向の記録に着 目すると，「装置あり」では「装置なし」に比べて全体 的に振幅が低く抑えられ，かつ波形が比較的短時間で変 
化するなど顕著な制振効果が認められる。

図一17，18は，図一16に示した速度波形のフーリエ スペクトル,および平面のオービットである。「装置あり」 のフーリエスペクトルでは $T$ 方向の 1 次振動数成分の ピークが大きく減少していることが分かる。それ以外の 振動数成分にはほとんど差は見られない。また，平面の オービットは，「装置なし」では $T$ 方向に卓越する楕円 形になっているのに対し，「装置あり」では $L$ 方向が卓 越する傾向となっている。

図一19は，速度の標準偏差の直交 2 方向に関する相 関性を示したものである。「装置なし」では $T$ 方向が $L$ 方向のほぼ 2 倍の值を示していたのに対して,「装置あ り」では逆に $T$ 方向の方がやや小さくなっており，「装 置なし」に対して $1 / 2 \sim 1 / 3$ に減少している。

また, 図一 20 は, 平均風速と速度の標準偏差の関係 を示したものである。この結果からも装置のなし・あり による顕著な差が認められ，本装置が風のような不規則 でやや非定常な外乱に対しても有効な制振効果を発揮し ていることが分かる。

\section{5. むすび}

水のスロッシングを利用した制振装置を奏建物へ適用 し，装置のなし・ありの雨ケースについて行った強制振 動実験, 自由振動試験, 常時微動測定, および風摇れ観 測結果から，本制振機構の定常，非定常外乱に対する制 振効果を検証した。これらの結果をまとめると以下のと おりである。

(1) 本装置を実建物に適用した結果，強制振動実験では 1 次共振点の振幅が大幅に娍少するとともに，自由振動 試験では建物の诚衰が大幅に増加し，顕著な制振効果が 認められた。

(2) 常時微動や風に対しても制振効果が認められ，本装 置が不規則外乱に対しても有効であること，および微振 動のレベルから作動することが確認されだ。

(3) 装置の加振実験から得られた流体力を用いる解析手 法による計算結果は実験結果よよい対応を示し, 文献 7) で提案した流体力モデルによる解析手法の妥当性が確認 された。

(4)本制振機構は, 近似的にはHousner モデルに基づ いた TMD 理論が適用可能である。

以上の結果, 本装置は調和振動のみならず，風や常時 微動のような不規則でやや非定常な外乱に対しても有効 に制振効果を発揮することが明らかになった。ただし， これらの実験・観測は小振幅域におけるものであり，今 後大振幅域における制振効果のデータの収集を図ってい く必要がある。さらに，流体力モデルによる装置一構造 物系の不規則振動に対する理論解の解明も今後に残され
ている課題である。

\section{・謝 辞}

本研究にあたり，大阪大学工学部教授井上 䇺博士， 神奈川大学工学部教授大熊武司博士から貴重なご助言を 賜りました。また，三井造船 (株) 鉄構土木事業本部の 佐藤哲也氏, 平野廣和博士, (株) 三井造船昭舅研究所 の平野雅祥博士，小林正典博士，三井建設 (株) 設計本 部の多田卓哉氏，荒木 聡氏からは，実験・解析手法に ついて多大な協力を頂きました。ここに深く謝意を表し ます。

\section{参考文献}

1) Modi, V.J. and F. Welt : Vibration Control Using Nutation Dampers, Proc. Int. Conf. on Flow Induced Vibration, England, pp. 369-376, 1987

2）藤井邦雄，佐藤孝典，大築民大：液体のスロッシング如 利用した制振装置一Tuned Sloshing Damperについて 一, 日本建築学会大会学術講演梗概集 B, pp. 1483-1484, 1987 年 10 月

3）藤野陽三，パチェコ B. ，チェイサリP., 藤井邦雄：同調 液体ダンパー（TLD）の基本特性に関する実験的検討一 円筒容器の場合一, 構造工学論文集, $\mathrm{Vol} .34 \mathrm{~A}$, pp. 603-616, 1988 年 3 月

4）宮田利雄，山田均，斎藤善昭：塔状構造物制振用水槽 ダンパーの開発, 構造工学論文集, Vol. 34 A, pp. 617-626, 1988 年 3 月

5) 坂井藤一, 高枝新伍, 玉木利裕：液柱管ダンパー ( Tuned Liquid Column Damper) の提案一液柱管の振動特性一, 構造工学論文集, Vol. 35 A, II , pp. 543-552, 1.989 年 3 月

6）田村幸雄, V.J. Modi, 今井一郎, 関 広之, 高坂 隆, 小林裕明：塔状構造物の制振に関する研究 (1)-NUTATION DAMPER の基本的な特性と減衰材の効舁 一, 日本建築学会関東支部研究報告集, pp. 37-40, 1990 年 1 月

7）野路利幸, 吉田英敏, 立見栄司ほか：水のスロッシング を利用した制振装置の研究 (その1) 装置の流体力特性 と制振効果の特性, 日本建築学会論文報告集, 第 411 号, pp. $97 \sim 105,1990$ 年 5 月

8）野路利幸, 吉田英敏, 立見栄司ほか：スロッシングを利 用した制振装置の研究 (その1) (その3), 日本建築学 会学術講演梗概集 B，pp. 867-872，1987 年 10 月

9）野路利幸, 吉田英敏, 立見栄司ほか：スロッシングを利 用した制振装置の研究 (その4) (その7)，日本建築学 会学術講演梗概集 B, pp. 563-570，1988 年 10 月

10）野路利幸, 吉田英敏, 立見栄司ほか：スロッシングを利 用した制振装置の研究 (その 8) (その11), 日本建築学 会学術講演梗概集 B，pp.615-622，1989 年 10 月

11) Housner, G.W. : Dynamic Pressures on Accelerated Fluid Containers, Bulletin of the Seismological Society of America, pp 15-35, 1957

(1990 年 5 月 10 日原稿受理, 1990 年 10 月 25 日採用決定) 